\title{
Critical Success Factors for Supply Chain Sustainability in the Wood Industry: An Integrated PCA-ISM Model
}

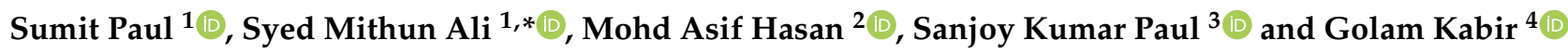 \\ 1 Department of Industrial and Production Engineering, Bangladesh University of Engineering and Technology, \\ Dhaka 1000, Bangladesh; sumitpaul398@gmail.com \\ 2 Mechanical Engineering Section, University Polytechnic, Faculty of Engineering and Technology, \\ Aligarh Muslim University, Aligarh 202001, India; hasan_in@hotmail.com \\ 3 UTS Business School, University of Technology Sydney, Ultimo, NSW 2007, Australia; Sanjoy.Paul@uts.edu.au \\ 4 Industrial Systems Engineering, Faculty of Engineering and Applied Science, University of Regina, Regina, \\ SK S4S 0A2, Canada; golam.kabir@uregina.ca \\ * Correspondence: mithun@ipe.buet.ac.bd or syed.mithun@gmail.com
}

Citation: Paul, S.; Ali, S.M.; Hasan, M.A.; Paul, S.K.; Kabir, G. Critical Success Factors for Supply Chain Sustainability in the Wood Industry: An Integrated PCA-ISM Model. Sustainability 2022, 14, 1863. https://doi.org/10.3390/ su14031863

Academic Editor: Luigi Roselli

Received: 30 December 2021

Accepted: 4 February 2022

Published: 6 February 2022

Publisher's Note: MDPI stays neutral with regard to jurisdictional claims in published maps and institutional affiliations.

Copyright: (C) 2022 by the authors. Licensee MDPI, Basel, Switzerland. This article is an open access article distributed under the terms and conditions of the Creative Commons Attribution (CC BY) license (https:// creativecommons.org/licenses/by/ $4.0 /)$.

\begin{abstract}
Due to the increasing popularity of cost-based outsourcing and growing stakeholder concern about environmental, social, and technological issues, supply chain sustainability is vital in both developed and emerging economies. Bangladesh is an emerging economy and wood industry of Bangladesh is suffering from severe sustainability issues besides its growth. Hence, this article aims to examine the critical success factors (CSFs) for sustainability in the Bangladeshi wood industry, which is crucial to help supply chain managers engage in achieving sustainable development goals. This research investigated the CSFs and uncovered their interdependencies through the development of a methodology integrating a literature review, principal component analysis (PCA), interpretive structural modelling (ISM), and Matriced Impacts Croises Multiplication Appliquee aunClassement (MICMAC) techniques. PCA $(n=150)$ was used to identify and rank the CSFs for sustainability in the Bangladeshi wood industry while ISM $(n=9)$ and MICMAC were used to determine the driving and dependence power of the CSFs. The findings reveal that research and development, supplier relations, and using eco-friendly technology are the most significant CSFs of the Bangladeshi wood industry. Indispensable links revealing the driving and dependence power among the CSFs were also reported. To the best of our knowledge, this study is the first of its kind that examined the CSFs for supply chain sustainability in the Bangladeshi wood industry. The proposed methodology and findings will help managers in the Bangladeshi wood industry as well as other similar industries to understand the CSFs and reduce the complexity of decision-making in managing business process towards sustainability journey.
\end{abstract}

Keywords: sustainability; wood industry; principal component analysis; interpretive structural modelling

\section{Introduction}

Sustainability in the context of business refers to decisions that have an impact on the future conditions of nature, society, and business [1-3]. The concept of a sustainable supply chain is viewed as a measure that pertains to profit and loss-but also broader social and environmental concerns $[4,5]$. In other words, sustainability centres around reducing a business's harmful impacts on people, society, and the environment while still enhancing value for customers, business partners, and stakeholders [6]. Aside from meeting social and environmental expectations, sustainability reduces cost and reputational risk, boosts revenue, and ensures long-term success [7].

There are many barriers to the successful implementation of sustainable supply chain management (SSCM), though these barriers vary in their significance [8,9]. Therefore, there is a strong need for organizations to identify the dominant factors (i.e., the critical success factors [CSFs]) to effectively pursue SSCM practices [10]. To help organizations adopt 
effective SSCM practices, this paper develops a methodology aimed at investigating CSFs for sustainability in the Bangladeshi wood industry and constructing a structural model to understand the interactive relationships among these CSFs.

The Bangladeshi wood industry mainly consists of paper and furniture manufacturing. Bangladeshi paper is manufactured using wood pulp, which is generally collected from forests [11]. It is growing every year. In fact, it is currently going through a transition period; demand for wood products is expanding due to their increased affordability and the country's increasing population. The Bangladeshi furniture industry, which rapidly transformed from a cottage industry to a heavily mechanized mass-production industry in the early 1990s, mainly produces home and office furniture. According to the Bangladesh Furniture Industries Owners Association, Bangladeshi furniture manufacturers import about $60 \%$ of their raw materials. However, local manufacturers are currently expanding their reach in the international market. Bangladesh's furniture export market has now expanded to 202 destinations in the world. It has grown to $\$ 74.9$ million in 2019 from $\$ 31.4$ million in 2013 [12]. Furniture industry has been included as one of the highest priority sectors in Bangladesh's Export Policy 2018-2021 and declared as a "thrust sector". The domestic furniture industry is characterized by the dominance of medium, small, and micro enterprises all over the country and some bigger competitors at major cities like Dhaka, Barisal, Bogra, Chittagong, Manikganj, Narayanganj, and Sylhet. Some prominent furniture factories are situated at Badda, Gandaria, Chankharpul, Madanpur, Mirpur, Shahjahanpur, Panthapath, Sutrapur, Gazipur, and Shyampur. According to some studies, there are around 81 medium sized enterprises, and around 71,000 micro and small enterprises and around 75,000 engaged enterprises in the industry. The sector contributes to around 9 percent of the manufacturing employments in Bangladesh. Almost 80 percent of the jobs are basic production works, and rest of the percentages are related to sophisticated skills like furnishing, marketing, assembling, and designing [13]. In general, according to the life-cycle approach, the most significant environmental impacts of the furniture industry can be divided into three groups: energy and raw material consumption; emission of chemical substances; and waste generation [14,15]. As a result, low consumption, low emission, and low pollution constitute the primary focus of low-carbon economic development. Hence, the low-carbon development of renewable wood resources is very important for sustainability in the wood industry. The wood industry involves several negative environmental externalities, including wastewater production and volatile organic compound generation. Due to these ecological issues-as well as deforestation-the wood industry is vulnerable to sustainability issues [16,17]. The sustainable development of the wood industry would entail an optimized wood-production cycle and improved waste-management procedures [18]. Overall, it is clear that an analysis of the CSFs for sustainability in wood industries is warranted. The global competition in the wood sector put considerable pressure on researchers to think about concerns over environmental conservation in the wood industry's supply-chain-planning process. Achieving sustainability in the wood supply chain is complex and poses numerous challenges [19].

Bangladeshi wood industry uses both modern and indigenous technologies. Though the export-oriented and technology-intensive production processes, which includes sophisticated machineries, are being used for different operations, adopting modern technologies has been a major challenge for smaller enterprises. Moreover, many Bangladeshi firms lack required human and technical resources to maintain Enterprise Resource Planning (ERP) to ensure efficient production planning. With the emergence of E-commerce, information and communication technology is an important supply chain pillar, which connects consumers and firms with big consumers and retailers globally. This sector has been underdeveloped until now, which may improve in the near future. In addition to these, Bangladeshi furniture enterprises find it difficult to implement international certification systems [13].

Most of the SCM studies contain optimization of total cost equation to maximize the profit margin minimizing the variable demand and lead time uncertainty [1-3]. A recent study reviewed the assessment and optimization studies on wood supply chains that 
include at least one dimension of sustainability. They found that most of the papers included just one or two sustainability dimensions. Social responsibility was the least common dimension [20]. While these studies considered optimization models with deterministic parameters, none considered CSFs for SSCM in the wood industry. This study aims to fill this gap in the research.

This study incorporates principal component analysis (PCA), interpretive structural modelling (ISM), and Matriced Impacts Croises Multiplication Appliquee aunClassement (MICMAC) to evaluate the supply chain sustainability in the wood industry of Bangladesh. These three methods offer strong advantages. PCA has been used to identify and deconstruct CSFs using experts' opinions. ISM has been used to determine the driving and dependence power of CSFs. MICMAC has been used to divide CSFs into four categories: dependent, independent, autonomous, and linkage [21]. The comparison of the current study with relevant studies have been included to highlight the contributions.

The rest of this paper is organized as follows. Section 2 gives the related materials and methods. Section 3 presents the results and discussion. Section 4 concludes this paper.

\section{Materials and Methods}

\subsection{Conceptualization of Critical Success Factor}

Despite the importance of supply chain sustainability in the wood industry, there is a dearth of research on the CSFs for sustainability in the wood industry [22]. Zineldin et al. [23] identified the factors that affect supplier-dealer relationships by interviewing 114 purchasing managers in the Swedish wood industry. Quesada et al. [24] identified and ranked the CSFs for sustainability in the U.S. furniture industry using the five-point Likert scale. Daian et al. [25] assessed the generation of wood waste by Australian furniture companies and its associated costs to enhance sustainability standards in the Australian manufacturing sector. Looking at the Amish furniture industry, Dewitt et al. [26] demonstrated a link between Porter's cluster theory and supply chain management, providing evidence of their joint positive impact on firm competitiveness and performance. Moreover, Gomez et al. [27] identified the CSFs for sustainability in the U.S. pallet-manufacturing industry after surveying 1500 manufacturers. Quesada-Pineda et al. [28,29] analyzed and validated the CSFs that affect the supply chain of the U.S. pallet-manufacturing industry. Furthermore, they identified the external factors and business practices using the five-point Likert scale and PCA [24,25].

Penfield et al. [30] identified the characteristics of efficient hardwood sawmill supply chains through data envelopment analysis. Larsson et al. [31] conducted a literature survey to detail the potential of SSCM to solve the challenges of the Swedish woodproducts industry. Thị Thu Sương [32] identified the factors that influence supply chain collaboration in the Vietnamese wood-processing industry using a questionnaire survey. Romagnoli et al. [19] reviewed used wood-based products, linking them with supply chain sustainability. Kogler et al. [33] found that the combination of unimodal and multimodal transportation eliminates ill-timed plans and bottlenecks, making the wood supply chain more resilient. Recently, Ebrahimi et al. [34] applied a bi-objective supply chain model to a build-to-order environment in order to maximize profits and minimize downtime in wood supply chains. Susanty et al. [35] investigated circular economy practices in the traditional Indonesian wood industry. Chu et al. [36] provided data on pollutants and emissions through a life-cycle analysis to promote sustainability in the Chinese wood industry. Ratnasingam et al. [37] identified the CSFs for sustainability in the Malaysian panel-based furniture-manufacturing industry by surveying 20 manufacturers using a questionnaire survey and PCA; however, they did not identify the interdependent relationships among the CSFs. Navarro et al. [38] identified sustainable suppliers in the wood fibre supply industry by integrating the analytic hierarchy process (AHP) with the technique for order of preference by similarity to ideal solution (TOPSIS) methods.

There are some existing studies on SSCM in emerging economies that incorporate PCA, ISM, MICMAC, and other mathematical methods. Rajput et al. [39] integrated 
PCA, ISM, and DEMATEL to identify IoT enablers in Industry 4.0 and the relationships between these enablers. Chowdhury et al. [40] employed ISM and MICMAC to identify the CSFs for sustainability in the Bangladeshi ready-made garments industry and their interrelationships-though the authors were careful to note that their results are specific to the industry and region of study. Devi et al. [41] employed PCA, ISM, and MICMAC to analyze IoT enablers in Industry 4.0. The comparison of the current study with relevant studies is shown in Table 1 to highlight the contributions.

Table 1. Comparison of relevant studies with this study.

\begin{tabular}{cccc}
\hline Authors & Methods Used & Region of Study & Main Contribution \\
\hline Zineldin et al. [23] & Survey & Sweden & $\begin{array}{c}\text { Identifying factors influencing } \\
\text { supplier-dealer relationship }\end{array}$ \\
\hline Quesada et al. [24] & Survey using five-point Likert scale & USA & Identification and ranking of CSFs for sustainability \\
\hline Daian et al. [25] & Survey & Australia & $\begin{array}{c}\text { Assessment of generation of wod waste to enhance } \\
\text { sustainability standards }\end{array}$ \\
\hline Dewitt et al. [26] & Case study & USA & $\begin{array}{c}\text { Demonstration of a link between Porter's cluster } \\
\text { theory and supply chain management }\end{array}$ \\
\hline Gomez [27] & Survey & USA & $\begin{array}{c}\text { Identification of the CSFs for sustainability in the U.S. } \\
\text { pallet-manufacturing industry after } \\
\text { surveying 1500 manufacturers }\end{array}$ \\
\hline Ratnasingam et al. [37] & Survey and PCA & Malaysia & $\begin{array}{c}\text { Identification of the CSFs for sustainability in } \\
\text { panel-based furniture-manufacturing industry }\end{array}$ \\
\hline Navarro et al. [38] & Integration of AHP and TOPSIS & USA & $\begin{array}{c}\text { Identification of sustainable suppliers in the wood } \\
\text { fibre supply industry }\end{array}$ \\
\hline Rajput et al. [39] & Integration of PCA, ISM, and DEMATEL & India & $\begin{array}{c}\text { Identification of IoT enablers in Industry 4.0 and the } \\
\text { relationships between these enablers }\end{array}$ \\
\hline Chowdhury et al. [40] & Integration of ISM and MICMAC & Bangladesh & $\begin{array}{c}\text { Identification of the CSFs for sustainability in } \\
\text { ready-made garments industry and } \\
\text { their interrelationships }\end{array}$ \\
\hline Devi et al. [41] & Integration of PCA, ISM and MICMAC & India & Bangladesh \\
\hline This study & Integration of PCA, ISM and MICMAC & $\begin{array}{c}\text { Evaluation of valuate the supply chain sustainability } \\
\text { in the wood industry }\end{array}$ \\
\hline
\end{tabular}

This study identifies the CSFs for SSCM adoption in the Bangladeshi wood industry using both expert feedback and the existing literature. Therefore, we carried out a literature review in the initialization phase using several fundamental terms: "drivers for supply chain sustainability" OR "critical success factors of sustainable supply chain adoption" OR "CSFs in sustainable supply chain" OR "investigate and examine sustainable supply chain drivers." We used two popular scholarly databases-“"Google Scholar" and "ScienceDirect" - for this review. Table 2 details the 25 CSFs identified through the literature review. The CSFs have been contextualized for further analysis in the context of the Bangladeshi wood industry by considering input from industrial and academic experts.

Table 2. CSFs for Supply Chain Sustainability.

\begin{tabular}{|c|c|c|c|}
\hline S1. No. & Success Factor & Description & References \\
\hline 1 & Recycling and waste management (RWM) & $\begin{array}{l}\text { Recycling focuses on the regeneration of renewable resources after use. } \\
\text { The principles of waste management are elimination, reduction, reuse, } \\
\text { recovery, and disposal. }\end{array}$ & {$[38,39]$} \\
\hline 2 & Using eco-friendly technology (ET) & $\begin{array}{l}\text { Using eco-friendly technology that conserves energy and reduces } \\
\text { resource consumption. }\end{array}$ & {$[5,7]$} \\
\hline 3 & Sharing natural resources (NR) & The long-term availability and sharing of natural resources. & {$[40,41]$} \\
\hline 4 & Product responsibility (PR) & $\begin{array}{l}\text { Product responsibility covers the entire life cycle, including the raw } \\
\text { materials, product development, production, use, and recycling. }\end{array}$ & {$[7,42]$} \\
\hline 5 & $\begin{array}{l}\text { Designing products for recyclability, reusability, } \\
\text { and material recoverability (RRR) }\end{array}$ & $\begin{array}{l}\text { Designing for deconstruction to ensure that deconstruction processes } \\
\text { retain maximum material value. }\end{array}$ & {$[43,44]$} \\
\hline
\end{tabular}


Table 2. Cont.

\begin{tabular}{|c|c|c|c|}
\hline S1. No. & Success Factor & Description & References \\
\hline 6 & $\begin{array}{l}\text { Supplier environmental evaluation and } \\
\text { feedback (SEEF) }\end{array}$ & $\begin{array}{l}\text { Suppliers are evaluated on several criteria: no child labour, working } \\
\text { hours, no forced labour, no discrimination, employment compensation, } \\
\text { freedom of association, use of eco-friendly materials, and health and } \\
\text { safety practices. }\end{array}$ & {$[8,45]$} \\
\hline 7 & Using eco-friendly materials (EFM) & Using eco-friendly materials. & [46] \\
\hline 8 & Managing hazardous substances (MHS) & $\begin{array}{l}\text { Managing wood-industry-specific hazardous chemicals, which are } \\
\text { endorsed by the Occupational Safety and Health Regulations } 1996 \text { and } \\
\text { have specific safety requirements. }\end{array}$ & [47] \\
\hline 9 & Support from customers (SC) & $\begin{array}{l}\begin{array}{l}\text { Awareness among customers motivates manufacturers to produce } \\
\text { green products. }\end{array} \\
\text {. }\end{array}$ & [48] \\
\hline 10 & Training programs for supplier and vendors (SV) & Training, implementing special projects, and monitoring performance. & [49] \\
\hline 11 & $\begin{array}{l}\text { Collaborative RED with same-sector } \\
\text { companies }(R \mathcal{E} D)\end{array}$ & $\begin{array}{l}\text { Collaboration on green research and development with suppliers and } \\
\text { companies in the same sector. }\end{array}$ & [50] \\
\hline 12 & Flexible working arrangements (FWA) & $\begin{array}{l}\text { Flexible working_also known as flextime or flexitime-refers to } \\
\text { non-traditional working arrangements that consider employees' } \\
\text { personal needs, often involving working from home and flexible hours. }\end{array}$ & [7] \\
\hline 13 & Supplier evaluation and selection (SES) & $\begin{array}{l}\text { Environmental auditing and supplier evaluation to ensure that } \\
\text { products conform to regulations. }\end{array}$ & {$[36,51]$} \\
\hline 14 & Supplier relations $(S R)$ & $\begin{array}{l}\text { Supplier relations reflect the extent to which an organization has a } \\
\text { collaborative relationship with its suppliers. }\end{array}$ & {$[52,53]$} \\
\hline 15 & Stability in policy and regulations (PS) & $\begin{array}{l}\text { Stability in policies and regulations, which is often tied to } \\
\text { political stability. }\end{array}$ & [54] \\
\hline 16 & Health and safety (HS) & $\begin{array}{l}\text { Manual lifting, forceful gripping, wood dust, and hazardous } \\
\text { substances are the reported common risk factors in the wood industry. } \\
\text { Inhaling hazardous substances and getting caught in moving parts are } \\
\text { common injuries in the industry. The most prominent prior risk is } \\
\text { inadequate personal protective equipment. }\end{array}$ & {$[36,55]$} \\
\hline 17 & Gender diversity (GD) & $\begin{array}{l}\text { Fair representation of people of different genders at various stages of } \\
\text { the supply chain. }\end{array}$ & [56] \\
\hline 18 & Government legislation (GL) & $\begin{array}{l}\text { Regulations pressure suppliers and organizations to use } \\
\text { eco-friendly products and processes to improve } \\
\text { operational performances. }\end{array}$ & [57] \\
\hline 19 & Top management support (TMS) & $\begin{array}{l}\text { Top management support is crucial to the successful implementation } \\
\text { of SSCM. }\end{array}$ & [58] \\
\hline 20 & Resource management (RM) & $\begin{array}{l}\text { Optimal resource usage helps firms achieve economic sustainability in } \\
\text { the supply chain. }\end{array}$ & [59] \\
\hline 21 & Supplier audit (SA) & $\begin{array}{l}\text { Supplier audits have the potential to enhance supply chains' } \\
\text { environmental and social performance. }\end{array}$ & [60] \\
\hline 22 & Product quality $(P Q)$ & $\begin{array}{l}\text { Sustainable supply chains can be achieved by producing high-quality } \\
\text { products with a longer product life. }\end{array}$ & [36] \\
\hline 23 & Technological advancement and adaption (TAA) & $\begin{array}{l}\text { Willingness to research developing technologies and adopt new } \\
\text { technologies in the pursuit of greater sustainability. }\end{array}$ & {$[59,61]$} \\
\hline 24 & Technology transfer $(\mathrm{TT})$ & $\begin{array}{l}\text { Transferring technology to supply chain partners helps firms achieve } \\
\text { long-term sustainability. }\end{array}$ & [62] \\
\hline 25 & Information system (IS) & $\begin{array}{l}\text { Information systems impact SSCM on various processes, such as } \\
\text { planning, sourcing, and delivering, and at various levels, including } \\
\text { tactical operations and organizational strategy. }\end{array}$ & [63] \\
\hline
\end{tabular}

\subsection{Proposed Approach}

Our proposed approach is illustrated in Figure 1. From the selected factors in Table 2, we identified 10 CSFs through PCA while considering expert opinions that were collected through a questionnaire survey. PCA is a popular machine learning technique used to identify underlying patterns in multivariate data [64]. It extracts important information from a set of data and, using orthogonal transformation, represents them as a new set of linearly correlated variables, which are called principal components. Through PCA, 
we excluded 15 factors for increasing the consistency of the Kaiser-Meyer-Olkin (KMO) measure of adequacy and Bartlett's test of sphericity measurement.

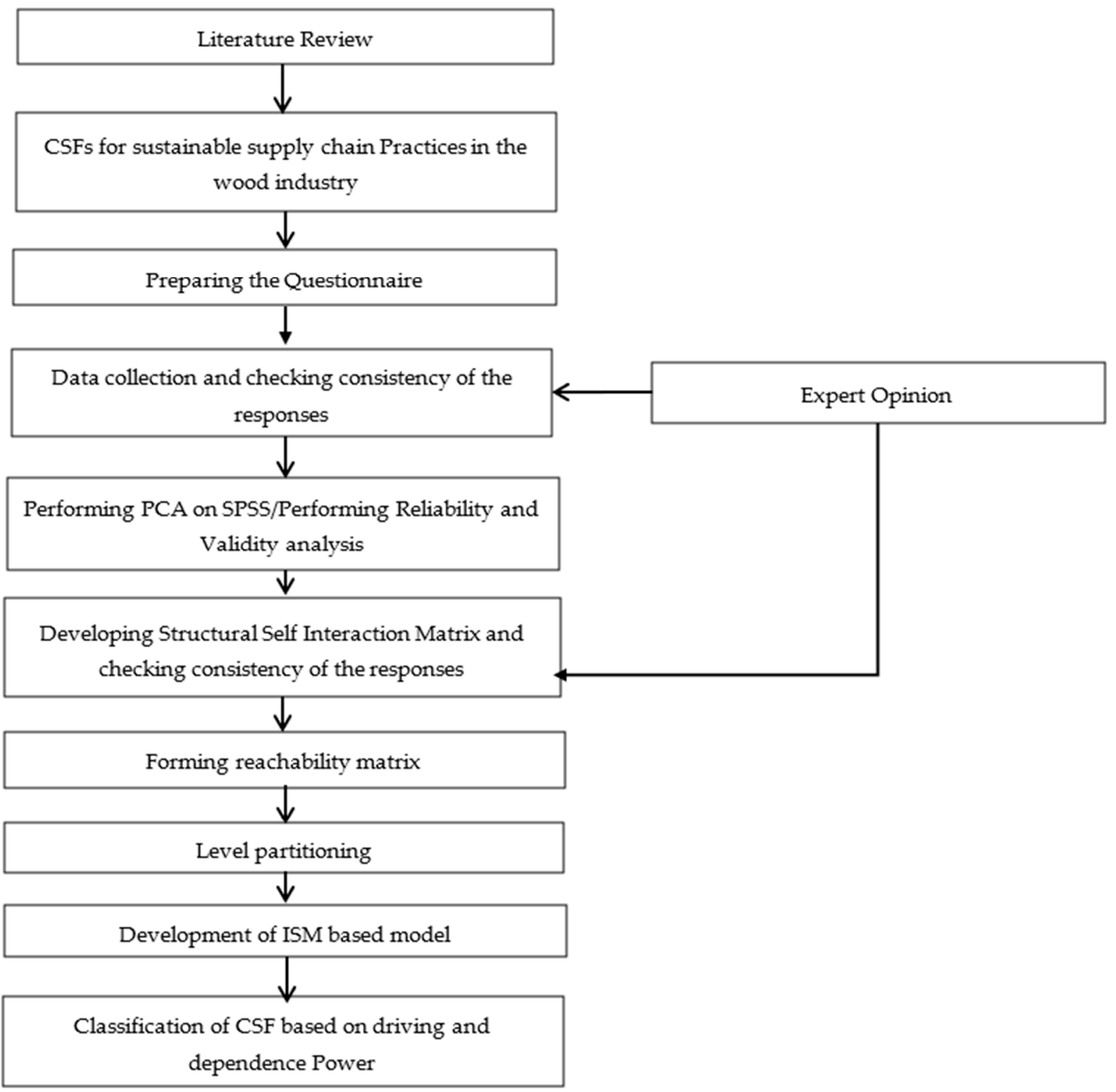

Figure 1. Proposed Approach.

After identifying CSFs for sustainability in the Bangladeshi wood industry and extracting them into four components, we employed ISM [65] and MICMAC to analyze the contextual relationships among the CSFs. ISM can be used as a systemic tool to identify contextual relationships; it is an interpretive tool, as the judgments of the groups decide the relationship between the variables. ISM is a structural method based on a mutual relationship from the complex set of elements; it is a modelling technique, as the specific relationships and overall structure are portrayed in a digraph model. It helps to impose order and direction on complex relationships. It is primarily intended as a group learning process-but individuals can also use it.

\subsubsection{Identifying CSFs Using PCA}

We developed a standard questionnaire based on the five-point Likert scale to identify the CSFs for sustainability in the Bangladeshi wood industry through PCA (Table A1 in Appendix A). We e-mailed the questionnaire to 150 experts-30 academics from Bangladeshi 
universities researching supply chains and 120 managers (30 quality managers, 50 supply chain managers, and 40 operational process managers) at 30 Bangladeshi paper mills and furniture-manufacturing companies (for expert profiles, see Table 3). After three months, we received responses from 93 of the experts (23 academics and 70 managers). Afterward, we consolidated the data and conducted a descriptive analysis in SPSS. PCA was employed to reduce the number of factors. The two most important results from PCA are total variance and the component matrix. Total variance computes explained variance, and the component matrix computes the weights of variables in a few easily interpretable factor components. PCA with varimax rotation was employed to divide the ten factors into four categories (14 factors were excluded for consistency of the PCA, and "Gender Diversity" was excluded for low factor loading). We employed varimax rotation because it maximizes the sum of the variance of square loading [62]. The minimum number of cases should be at least five times the number of items being analyzed [66].

Table 3. Expert profile.

\begin{tabular}{|c|c|c|c|c|}
\hline & $\begin{array}{c}\text { Organization } \\
\text { Type/Pseudocode }\end{array}$ & Designation & No. of Experts & $\begin{array}{l}\text { Average Work } \\
\text { Experience (n) }\end{array}$ \\
\hline \multirow{14}{*}{ Academia } & \multirow{3}{*}{ A001 } & Professor & 4 & $n>15$ \\
\hline & & Assistant professor & 2 & $n>5$ \\
\hline & & Associate professor & 1 & $n>7$ \\
\hline & \multirow{3}{*}{ A002 } & Professor & 3 & $n>10$ \\
\hline & & Assistant professor & 1 & $n>5$ \\
\hline & & Associate professor & 2 & $n>7$ \\
\hline & \multirow{3}{*}{ A003 } & Professor & 4 & $n>15$ \\
\hline & & Assistant professor & 3 & $n>5$ \\
\hline & & Associate professor & 2 & $n>7$ \\
\hline & \multirow{3}{*}{ A004 } & Professor & 2 & $n>15$ \\
\hline & & Assistant professor & 1 & $n>5$ \\
\hline & & Associate professor & 2 & $n>7$ \\
\hline & \multirow{2}{*}{ A005 } & Professor & 2 & $n>12$ \\
\hline & & Assistant professor & 1 & $n>7$ \\
\hline \multirow{6}{*}{ Industry } & \multirow{3}{*}{ Furniture } & Quality managers & 20 & $n>15$ \\
\hline & & Supply chain managers & 40 & $n>10$ \\
\hline & & Operation process managers & 10 & $n>10$ \\
\hline & \multirow{3}{*}{ Paper mills } & Quality managers & 15 & $n>10$ \\
\hline & & Supply chain managers & 10 & $n>10$ \\
\hline & & Operation process managers & 30 & $n>10$ \\
\hline Total & & & 150 & \\
\hline
\end{tabular}

In this study, we analyzed 93 experts' responses against 11 factors. To quantify the degree of interconnections among the variables and verify the appropriateness of the analysis, we tested sampling adequacy using the KMO measure of adequacy and Bartlett's test of sphericity. The KMO measure of adequacy was $0.948(>0.5)$, and the significance value of Bartlett's test of sphericity was $0.00(<0.4)$; Cronbach's alpha was 0.93, which is substantially greater than 0.7 . These figures demonstrate high internal consistency for the obtained data [67]. Gender diversity was excluded, as it exhibited a factor loading below 0.6 after having a round-table discussion with 15 of our 150 experts.

Considering our experts' input, we selected, ranked, and divided the CSFs into four categories using PCA. The rankings and categories are presented in Tables 4 and 5, respectively.

\subsubsection{Identification of the CSFs' Driving and Dependence Power}

Step 1: Developing a Structural Self-Interaction Matrix (SSIM): In order to develop an SSIM (Table 6), one professor from each university (total 5) and two industrial experts from furniture enterprises and two industrial experts from paper mills were invited for a round table discussion. The sample questionnaire for the discussion is in Appendix A After the round table discussion, according to the experts' opinion, the SSIM was developed. 
We used the following four symbols to find the direction of interaction between two CSFs (e.g., $i$ and $j$ ):

- V-CSF: $i$ facilitates reaching $j$

- A-CSF: $j$ facilitates reaching $i$

- X-CSF: $i$ and $j$ facilitate reaching each other

- O-CSF: $i$ and $j$ are not connected

Table 4. CFS ranking from PCA.

\begin{tabular}{|c|c|c|c|c|c|c|c|}
\hline \multirow{2}{*}{ CSFs } & \multicolumn{4}{|c|}{$\begin{array}{l}\text { Rotated Component Matrix } \\
\text { (Factor Loading Less than } 0.1 \text { is Omitted) }\end{array}$} & \multirow{2}{*}{ Mean } & \multirow{2}{*}{$\begin{array}{l}\text { Standard } \\
\text { Deviation }\end{array}$} & \multirow{2}{*}{ Rank } \\
\hline & $\begin{array}{c}\text { Component } \\
1\end{array}$ & $\begin{array}{c}\text { Component } \\
2\end{array}$ & $\begin{array}{c}\text { Component } \\
3\end{array}$ & $\begin{array}{c}\text { Component } \\
4\end{array}$ & & & \\
\hline R\&D & 0.818 & & & & 3.85 & 0.706 & 1 \\
\hline SR & & & 0.857 & & 3.84 & 0.680 & 2 \\
\hline $\mathrm{ET}$ & & & & 0.930 & 3.84 & 0.595 & 2 \\
\hline HS & & 0.875 & & & 3.81 & .711 & 3 \\
\hline TMS & 0.690 & & & & 3.08 & 1.106 & 4 \\
\hline $\mathrm{RM}$ & 0.689 & & & & 3.02 & 1.032 & 5 \\
\hline PQ & 0.681 & & & & 2.40 & 1.561 & 6 \\
\hline $\mathrm{TT}$ & 0.744 & & & & 2.14 & 1.089 & 7 \\
\hline TAA & 0.784 & & & & 2.06 & 1.051 & 8 \\
\hline IS & 0.770 & & & & 2.06 & 1.030 & 9 \\
\hline \multicolumn{3}{|c|}{$\begin{array}{l}\text { Extraction Method: Principal Component Analysis. } \\
\text { Rotation Method: Varimax with Kaiser } \\
\text { Normalization. }\end{array}$} & \multicolumn{5}{|c|}{$\begin{array}{l}\text { Cronbach alpha-0.93 } \\
\text { Kaiser-Meyer-Olkin Measure of Sampling Adequacy-0.948 } \\
\text { Approx. Chi-Square-859.184 }\end{array}$} \\
\hline
\end{tabular}

Table 5. Categories extracted from PCA.

\begin{tabular}{|c|c|}
\hline Extracted Components & CSFs Selected from PCA \\
\hline $\begin{array}{c}\text { Product quality and well-being of the } \\
\text { organization }\end{array}$ & $\begin{array}{c}\text { Collaborative Research \& Development with same sector companies (R\&D) } \\
\text { Product quality (PQ) } \\
\text { Transferring technology to suppliers and vendors (TT) } \\
\text { Information System (IS) } \\
\text { Resource Management (RM) } \\
\text { Technology advancement and adaption (TAA) } \\
\text { Top management support (TMS) }\end{array}$ \\
\hline Health and safety & Health and safety (HS) \\
\hline Supplier relations & Supplier relations (SR) \\
\hline Environment friendly technology & Use of environment friendly technology (ET) \\
\hline
\end{tabular}

Table 6. SSIM for the CSFs to Apply SSCM Practices in the Bangladeshi Furniture Industry.

\begin{tabular}{|c|c|c|c|c|c|c|c|c|c|}
\hline CSFs & ET & SR & HS & TMS & TAA & $\mathbf{R M}$ & IS & $\mathrm{TT}$ & $P Q$ \\
\hline R\&D & $\mathrm{V}$ & $\mathrm{O}$ & $\mathrm{V}$ & A & $x$ & $\mathrm{~V}$ & $x$ & $\mathrm{~V}$ & $\mathrm{~V}$ \\
\hline PQ & $x$ & $\mathrm{~A}$ & $\mathrm{~V}$ & A & A & A & $\mathrm{A}$ & A & \\
\hline$\hat{\mathrm{TT}}$ & $\mathrm{V}$ & V & $\mathrm{O}$ & A & A & $\mathrm{V}$ & $\mathrm{V}$ & & \\
\hline IS & $\mathrm{O}$ & V & $\mathrm{O}$ & A & $X$ & V & & & \\
\hline $\mathrm{RM}$ & $\mathrm{O}$ & $\mathrm{O}$ & $\mathrm{O}$ & A & A & & & & \\
\hline TAA & $\mathrm{V}$ & $\mathrm{O}$ & $\mathrm{V}$ & A & & & & & \\
\hline TMS & $\mathrm{V}$ & $\mathrm{V}$ & V & & & & & & \\
\hline HS & A & $\mathrm{O}$ & & & & & & & \\
\hline SR & $\mathrm{O}$ & & & & & & & & \\
\hline ET & & & & & & & & & \\
\hline
\end{tabular}


Using these four symbols, we developed an SSIM for implementing SSCM practices throughout the Bangladeshi furniture industry, which is presented in Table 6.

Step 2: Forming the Reachability Matrix: We transformed the SSIM into an initial reachability matrix. It is a binary matrix that contains 0 and 1 . It also follows certain rules, which are as follows:

Rule 1: For every $\mathrm{V}, 1$ for $(i, j)$ and 0 for $(j, i)$

Rule 2: For every A, 0 for $(i, j)$ and 1 for $(j, i)$

Rule 3: For every $\mathrm{X}, 1$ for $(i, j)$ and 1 for $(j, i)$

Rule 4: For every $\mathrm{O}, 0$ for $(i, j)$ and 0 for $(j, i)$

Following these rules, we constructed an initial reachability matrix (Table 7) and the final reachability matrix (Table 8 ), which integrates the transitive relationships among the factors $[66,68]$. The driving power and the dependence power of each factor have also been calculated, as shown in Table 8. TMS has the highest driving power, and HS has the highest dependence power.

Table 7. Initial Reachability Matrix for the CSFs to Apply SSCM Practices in the Bangladeshi Furniture Industry.

\begin{tabular}{lcccccccccc}
\hline \multicolumn{1}{c}{ CSFs } & 1. R\&D & 2. PQ & 3. TT & 4. IS & 5. RM & 6. TAA & 7. TMS & 8. HS & 9. SR & 10. ET \\
\hline 1. R\&D & 1 & 1 & 1 & 1 & 1 & 1 & 0 & 1 & 0 \\
2. PQ & 0 & 1 & 0 & 0 & 0 & 0 & 0 & 1 & 0 \\
3. TT & 0 & 1 & 1 & 1 & 1 & 0 & 0 & 0 & 1 \\
4. IS & 1 & 1 & 0 & 1 & 1 & 1 & 0 & 0 & 1 \\
5. RM & 0 & 1 & 0 & 0 & 1 & 0 & 0 & 0 & 0 & 0 \\
6. TAA & 1 & 1 & 1 & 1 & 1 & 1 & 0 & 1 & 0 \\
7. TMS & 1 & 1 & 1 & 1 & 1 & 1 & 1 & 1 & 1 \\
8. HS & 0 & 0 & 0 & 0 & 0 & 0 & 0 & 1 & 0 & 1 \\
9. SR & 0 & 1 & 0 & 0 & 0 & 0 & 0 & 0 & 0 \\
10. ET & 0 & 1 & 0 & 0 & 0 & 0 & 0 & 1 & 0 & 0 \\
\hline
\end{tabular}

Table 8. Final Reachability Matrix for the CSFs to Apply SSCM Practices in the Bangladeshi Furniture Industry.

\begin{tabular}{cccccccccccc}
\hline CSFs & R\&D & PQ & TT & IS & RM & TAA & TMS & HS & SR & ET & Driving Power \\
\hline R\&D & 1 & 1 & 1 & 1 & 1 & 1 & 0 & 1 & 1 & 1 & 9 \\
PQ & 0 & 1 & 0 & 0 & 0 & 0 & 0 & 1 & 0 & 1 & 1 \\
TT & 0 & 1 & 1 & 1 & 1 & 0 & 0 & 1 & 1 & 1 & 7 \\
IS & 0 & 1 & 0 & 1 & 1 & 0 & 0 & 1 & 1 & 1 & 1 \\
RM & 0 & 1 & 0 & 0 & 1 & 0 & 0 & 1 & 0 & 1 & 4 \\
TAA & 1 & 1 & 1 & 1 & 1 & 1 & 0 & 1 & 1 & 1 & 9 \\
TMS & 1 & 1 & 1 & 1 & 1 & 1 & 1 & 1 & 1 & 1 & 10 \\
HS & 0 & 0 & 0 & 0 & 0 & 0 & 0 & 1 & 0 & 0 & 1 \\
SR & 0 & 1 & 0 & 0 & 0 & 0 & 0 & 1 & 1 & 1 & 4 \\
ET & 0 & 1 & 0 & 0 & 0 & 0 & 0 & 1 & 0 & 1 & 9 \\
Dependence Power & 3 & 9 & 4 & 5 & 6 & 3 & 1 & 10 & 6 & 9 & 56 \\
\hline
\end{tabular}

Step 3: Level Partitioning: From the final reachability matrix, we derived the reachability and antecedent sets for each factor. The reachability set comprises the factor itself and the other factors that it may facilitate. The antecedent set consists of the factor itself and the other factors that may influence it. We also calculate the intersection of these two sets for each CSF. If a CSF's reachability and intersection sets are the same, the CSF is regarded to be at level 1 [55,69]. After the first iteration, we discarded the level-1 CSF and continued the same procedure until all of the CSFs' levels were identified. The final partitioning result is shown in Table 9. In this case, HS is at level 1 and lies at the top of the ISM hierarchy. TMS is at the last level and lies at the bottom of the ISM hierarchy. 
Table 9. Level-Partitioning Results from the Final Reachability Matrix.

\begin{tabular}{ccccc}
\hline CSF & Reachability Set & Antecedent Set & Intersection Set & Level \\
\hline R\&D & $1,2,3,4,5,6,8,9,10$ & $1,6,7$ & 1,6 & 6 \\
PQ & $2,8,10$ & $1,2,3,4,5,6,7,9,10$ & 2,10 & 2 \\
TT & $2,3,4,5,8,9,10$ & $1,3,6,7$ & 3 & 5 \\
IS & $2,4,5,8,9,10$ & $1,3,4,6,7$ & 4 & 4 \\
RM & $2,5,8,10$ & $1,3,4,5,6,7$ & 5 & 3 \\
TAA & $1,2,3,4,5,6,8,9,10$ & $1,6,7$ & 1,6 & 6 \\
TMS & $1,2,3,4,5,6,7,8,9,10$ & 7 & 7 & 7 \\
HS & 8 & $1,2,3,4,5,6,7,8,9,10$ & 8 & 1 \\
SR & $2,8,9,10$ & $1,3,4,6,7,9$ & 9 & 3 \\
ET & $2,8,10$ & $1,2,3,4,5,6,7,9,10$ & 2,10 & 2 \\
\hline
\end{tabular}

Step 4: Developing an ISM-Based Model: We identified seven levels from level partitioning in Table 9 with CSF 8 at level 1, CSFs 2 and 10 at level 2, CSFs 5 and 9 at level 3, CSF 4 at level 4, CSF 3 at level 5, CSFs 1 and 6 at level 6, and CSF 7 at level 7. After placing all of the CSFs at their level, we depicted a relationship between the CSFs as per the final reachability matrix (Table 8 using directional arrows, resulting in an ISM-based model, as shown in Figure 2).

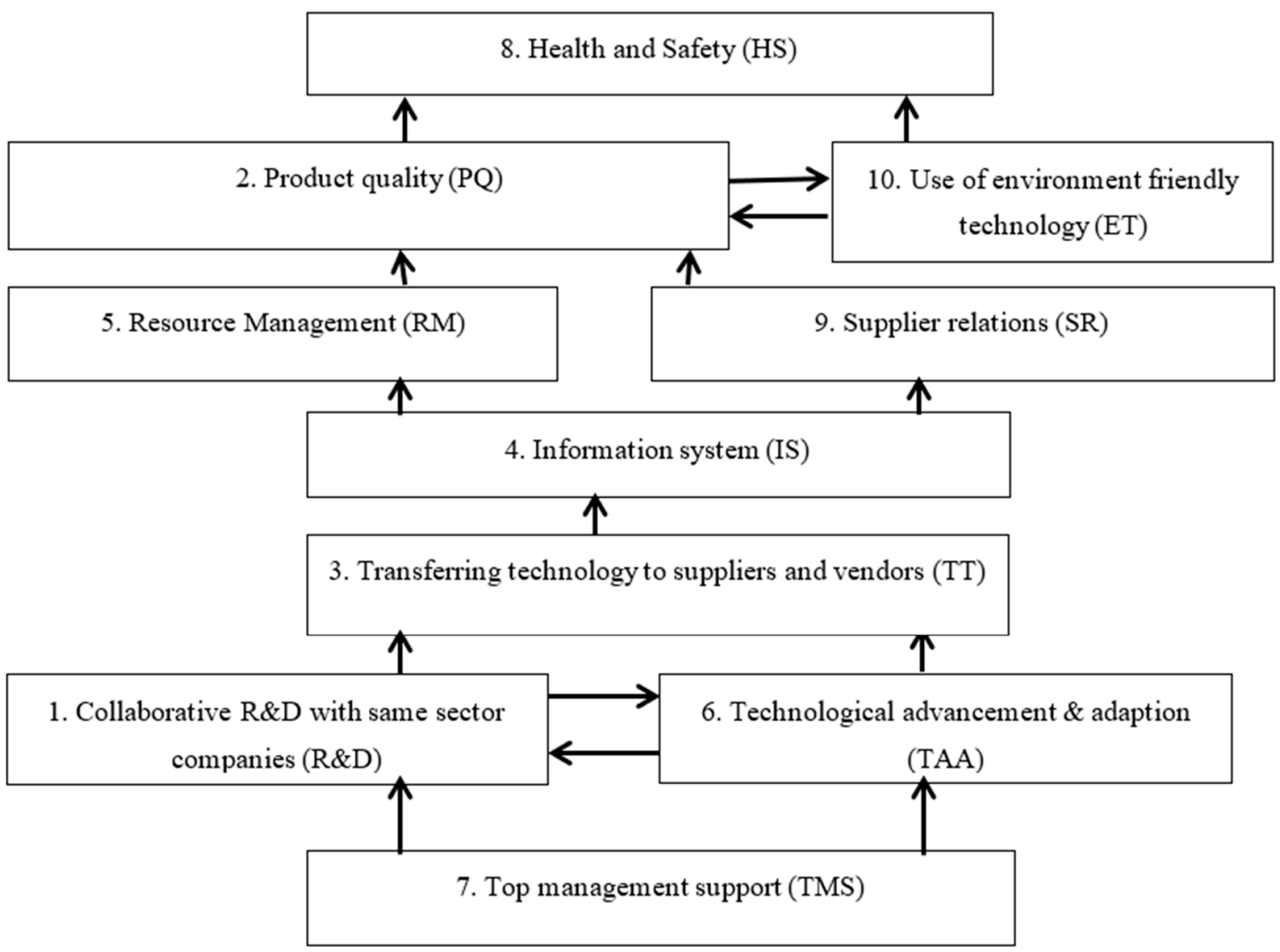

Figure 2. ISM Model for sustainable supply chain in the wood industry.

Step 5: MICMAC Analysis: MICMAC effectively corresponds to cross-impact matrix multiplication applied to classification $[5,7,9,34,70]$. MICMAC was developed based on the multiplication properties of metrics. We employed it in this paper to gain further insight into our ISM-based model [55] and to evaluate the CSFs from the implementation perspective. It involves the classification of the identified CSFs based on their dependence and driving power, which we determined in the final reachability matrix. 
MICMAC entails a graphical representation of the factors-based on their driving and dependence power-in four clusters: autonomous, dependent, linkage, and independent. Autonomous factors have weak dependence power and weak driving power. Dependent factors have strong dependence power but weak driving power. Linkage factors have strong dependence power and strong driving power. Independent factors have strong driving power but weak dependence power. Figure 3 illustrates the categorization of the CSFs into these four regions to evaluate the implementation of SSCM practices.

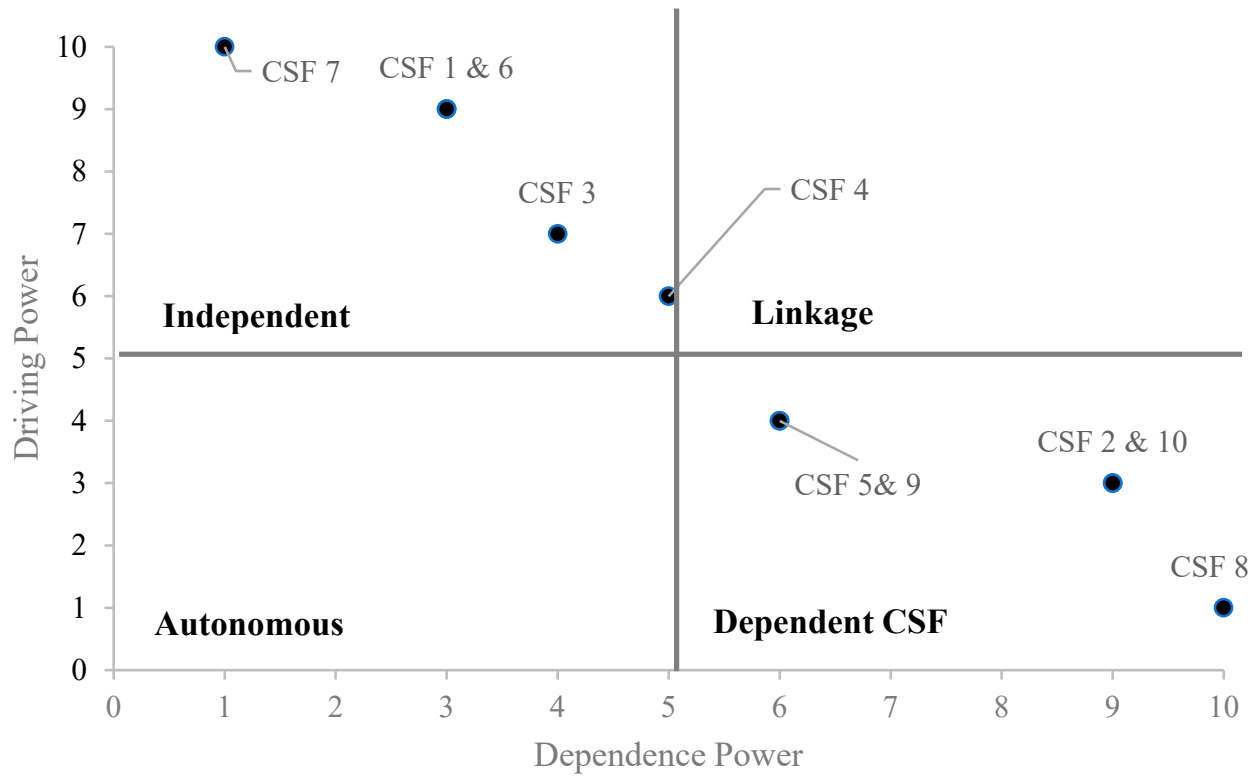

Figure 3. Driving power and dependence power diagram.

Figure 3 demonstrates that there is no autonomous CSF that shows that all ten of the considered CSFs are relevant to this study. We found CSFs 2, 5, 8, 9, and 10 (product quality, resource management, health and safety, supplier relations, and using eco-friendly technology, respectively) to be dependent and CSFs 1, 3, 6, and 7 (collaborative R\&D with same-sector companies, transferring technology to suppliers and vendors, technology advancement and adaption, and top management support, respectively) to be independent. Although CSF 4 (information system) lies on the border separating linkage and independent CSFs, it may be a linkage CSF for all practical purposes $[68,69,71]$. Independent CSFs are viewed as a top priority for implementation in SSCM practices, as they pave the way for efficiently and effectively implementing linkage and dependent CSFs.

\subsubsection{Model Validation}

The SSIM, ISM, and MICMAC analyses were shared with all of the respondents, whom we asked to share their critical opinions on the study. The study was generally well-received and appreciated, though a few questioned the lack of an interaction between CSF 5 (resource management) and CSF 9 (supplier relations). We concluded that the lack of this interaction is because the Bangladeshi wood industry is in a development phase, transitioning from a non-sustainable to a sustainable path; this requires organizations to develop relations with new suppliers who are willing to follow a sustainable path and sacrifice their relationships with old suppliers who are not as eager to adopt SSCM practices. This interpretation convinced all the participants, validating the model.

\section{Results and Discussions}

Sustainability has become a global concern. To remain competitive in both domestic and international markets, SSCM practices are a must for Bangladeshi furniture companies. Some Bangladeshi furniture manufacturers and paper mills have international suppliers and customers who have begun to implement sustainability measures-this will inevitably 
lead to the further spread of SSCM practices throughout the Bangladeshi wood industry. Without understanding the CSFs, however, organizations cannot properly pursue a sustainable supply chain. Based on experts' opinions, this study identified ten CSFs using PCA, as shown in Table 5. It then incorporated these ten CSFs into an ISM-based model (Figure 2) followed by MICMAC (Figure 3) based on the inputs from the ISM-based model. PCA helped to identify and rank the most important CSFs. ISM was used to uncover the relationships among those CSFs. Finally, MICMAC is helpful for managers to take appropriate actions at both the operational and strategic levels. Some of our most significant findings are as follows:

- $\quad$ Research and development (CSF 1), supplier relations (CSF 9), and using eco-friendly technology (CSF 10) are the top-ranked CSFs. In Bangladesh, there is a low level of $R \& D$, as it is an emerging economy. As a result, there is limited engagement with eco-friendly technology. Many companies are not interested in adopting an effluent treatment plant, as it would increase their operating costs. Additionally, good relationships with suppliers help organizations to ensure their long-term growth. The selected ten CSFs are divided into four categories: product quality and well-being of the organization, supplier relations, eco-friendly technology, and health and safety.

- There are no autonomous CSFs (Figure 3), suggesting that all of the considered CSFs are relevant to this study.

- The dependent CSFs (Figure 3) are product quality, resource management, health and safety, supplier relations, and using eco-friendly technology. These factors have weak driving power but strong dependence power. These CSFs certainly have associated costs in terms of resources, time, and focus that an organization may be unwilling to spend as part of its competitive strategy. To implement these CSFs, top management must actively support them.

- The independent CSFs (Figure 3) are collaborative R\&D with same-sector companies, transferring technology to suppliers and vendors, technology advancement and adaption, and top management support. These CSFs are vital to the implementation of dependent and linkage CSFs. As shown in Figure 2, top management support is the most important independent CSF in terms of pursuing SSCM practices, making it a driving force for the other three CSFs in this category. As the Bangladeshi wood industry is technologically lagging and more R\&D efforts are required to substitute wood with non-wood fibres in papermaking to limit deforestation [11,72,73], top management support is necessary to foster it.

- The only linkage CSF (Figure 3) is "information system." With high driving power and high dependence power, it has a significant role in the implementation of a sustainable supply chain. Moreover, its presence in the linkage category suggests that the Bangladeshi industry is aware of the potential requirement of information systems in the various processes and purposes of a business.

Our findings will help managers focus on the most important factors to build a resilient and sustainable supply chain. They will help them identify the critical areas on which they should focus to more effectively incorporate SSCM practices. In turn, our results will play a role in the paradigm shift towards sustainability that the Bangladeshi wood industry is currently undergoing.

The factors with high driving power are strategically important, while those with high dependence power are performance-oriented and result-oriented. Continual improvement of the independent factors will help organizations achieve superior results [74]. Focusing on the CSFs, organizations can acquire a competitive advantage by manufacturing ecofriendly products. In turn, their customers and stakeholders will push other companies to implement similar procedures to remain competitive.

\section{Managerial Implications}

The present study has significant practical implications for industrial managers and government policy makers to ensure sustainability in the wood industry. The model pre- 
sented here will help them understand the critical factors and their interrelationships in the context of the Bangladeshi wood industry. Moreover, it would be helpful for them to develop long-term and short-term plans to implement low-carbon economic development in the wood industry. Government plays significant roles in setting up policies and regulations to ensure low carbon economy, thereby enhancing sustainability in existing industrial sectors. These policies may encourage technological advancement, healthy and safe practices at factory workspace, collaborative R\&D, etc. Governmental policies may support all stakeholders involved in the management to mitigate probable challenges. This study would encourage policy makers of the Bangladesh government to take necessary steps to change their policies to help enterprises move towards sustainability.

In developed countries, the government allocates required funds to encourage sustainable practices at the industries. In addition to these, the government also allocates significant funds for R\&D activities to ensure use of advanced technologies, safety measures, low emission, and low pollution. However, in Bangladesh, there is very small or no funds for R\&D activities. Advanced technologies help to increase the profit margin [4]. The presented study would help the decision makers to increase funds for technology development and R\&D activities.

Training is required to make the human resources efficient. From the studies it is obvious that Bangladeshi wood furniture enterprises lack trained operators and human resources [16]. In addition to these, the enterprises find it difficult to accommodate international certifications and implement advanced technologies. The present study can encourage the managers and decision-makers to take necessary steps for train their workforces to improve quality of the products and reduce defective items [2].

In a nutshell, the major challenges for the wood industry of Bangladesh are mainly untrained workers, lack of R\&D activities, health and safety issues, lack of advanced technologies. The managers can take initiatives to overcome the challenges by implementing sustainable practices in their enterprises.

\section{Conclusions}

By pursuing sustainability, organizations can achieve positive business growth and a competitive advantage over others $[67,75]$. Of course, implementing SSCM practices is a challenging and complex task that requires a thorough interpretation of the sustainability index across an entire supply chain. Due to the subjectivity of the sustainability index, sustainability assessments require a transparent approach [76,77].

In this paper, we used PCA to identify and rank the most significant CSFs for sustainability in the Bangladeshi wood industry. We then identified the relationships among these CSFs using ISM. This study-which constituted the first attempt to evaluate the CSFs for sustainability in the Bangladeshi wood industry-found that "top management support" is the most significant driving factor, leading to higher "research and development" and "technology advancement and adaption" in the pursuit of a sustainable supply chain. The Bangladeshi wood industry is growing but lacks the presence of new, green technologies, which has a severe, negative impact on the environment. Despite the recent growth of this industry, it remains vulnerable to national and international pressure pertaining to environmental protection and labour rights, both of which largely depend on the awareness of top management. Continual R\&D and technological improvement are also important for improving product quality and addressing health and safety issues in this industry. Our proposed method will help company managers build a sustainable supply chain to compete in the international market.

This study has several limitations. First, it is highly dependent on experts' opinions. Hence, it could be biased based on their personal beliefs [40]. In addition, our results are both industry- and location-specific. Future research could evaluate other sectors (e.g., automotive industry, ready-made garments industry) and emerging economies. This study could also be implemented with weighted ISM, total ISM, or structural equation 
modelling to get better results. Fuzzy MICMAC analysis could also be employed to improve the model.

Author Contributions: Conceptualization, S.P., S.M.A., G.K., S.K.P.; methodology, S.P., S.M.A., G.K., S.K.P.; software, S.P.; validation S.P.; formal analysis, S.P.; investigation, S.P., S.M.A., G.K., S.K.P.; resources, S.M.A., G.K., S.K.P.; data curation, S.P.; writing—original draft preparation, S.P.; writingreview and editing, M.A.H., S.M.A., G.K., S.K.P.; visualization, S.P.; supervision, S.M.A., G.K., S.K.P.; project administration, S.M.A., G.K., S.K.P. All authors have read and agreed to the published version of the manuscript.

Funding: This research received no external funding.

Institutional Review Board Statement: Not applicable.

Informed Consent Statement: Informed consent was obtained from all subjects involved in the study.

Data Availability Statement: Not applicable.

Conflicts of Interest: The authors declare no conflict of interest.

\section{Appendix A}

Please respond to the following questionnaire. Please mark the factors on a five-point Likert scale: 1 (least important), 2 (not very important), 3 (important), 4 (very important), 5 (most important).

Table A1. Questionnaire for PCA.

\begin{tabular}{|c|c|c|}
\hline S1. No. & Success Factor & Description \\
\hline 1 & $\begin{array}{l}\text { Recycling and waste } \\
\text { management (RWM) }\end{array}$ & $\begin{array}{l}\text { Recycling focuses on the regeneration of renewable resources after use. } \\
\text { The principles of waste management are elimination, reduction, reuse, } \\
\text { recovery, and disposal. }\end{array}$ \\
\hline 2 & Using eco-friendly technology (ET) & $\begin{array}{l}\text { Using eco-friendly technology that conserves energy and reduces } \\
\text { resource consumption. }\end{array}$ \\
\hline 3 & Sharing natural resources (NR) & The long-term availability and sharing of natural resources. \\
\hline 4 & Product responsibility (PR) & $\begin{array}{l}\text { Product responsibility covers the entire life cycle, including the raw } \\
\text { materials, product development, production, use, and recycling. }\end{array}$ \\
\hline 5 & $\begin{array}{l}\text { Designing products for recyclability, } \\
\text { reusability, and material } \\
\text { recoverability (RRR) }\end{array}$ & $\begin{array}{l}\text { Designing for deconstruction to ensure that deconstruction processes } \\
\text { retain maximum material value. }\end{array}$ \\
\hline 6 & $\begin{array}{l}\text { Supplier environmental evaluation and } \\
\text { feedback (SEEF) }\end{array}$ & $\begin{array}{c}\text { Suppliers are evaluated on several criteria: no child labour, working hours, } \\
\text { no forced labour, no discrimination, employment compensation, freedom } \\
\text { of association, use of eco-friendly materials, and health and } \\
\text { safety practices. }\end{array}$ \\
\hline 7 & Using eco-friendly materials (EFM) & Using eco-friendly materials. \\
\hline 8 & Managing hazardous substances (MHS) & $\begin{array}{l}\text { Managing wood-industry-specific hazardous chemicals, which are } \\
\text { endorsed by the Occupational Safety and Health Regulations } 1996 \text { and } \\
\text { have specific safety requirements. }\end{array}$ \\
\hline 9 & Support from customers (SC) & $\begin{array}{l}\text { Awareness among customers motivates manufacturers to produce } \\
\text { green products. }\end{array}$ \\
\hline 10 & $\begin{array}{c}\text { Training programs for supplier and } \\
\text { vendors (SV) }\end{array}$ & Training, implementing special projects, and monitoring performance. \\
\hline 11 & $\begin{array}{l}\text { Collaborative R\&D with same-sector } \\
\text { companies (R\&D) }\end{array}$ & $\begin{array}{l}\text { Collaboration on green research and development with suppliers and } \\
\text { companies in the same sector. }\end{array}$ \\
\hline 12 & Flexible working arrangements (FWA) & $\begin{array}{l}\text { Flexible working-also known as flextime or flexitime-refers to } \\
\text { non-traditional working arrangements that consider employees' personal } \\
\text { needs, often involving working from home and flexible hours. }\end{array}$ \\
\hline
\end{tabular}


Table A1. Cont.

\begin{tabular}{|c|c|c|}
\hline Sl. No. & Success Factor & Description \\
\hline 13 & Supplier evaluation and selection (SES) & $\begin{array}{l}\text { Environmental auditing and supplier evaluation to ensure that products } \\
\text { conform to regulations. }\end{array}$ \\
\hline 14 & Supplier relations (SR) & $\begin{array}{l}\text { Supplier relations reflect the extent to which an organization has a } \\
\text { collaborative relationship with its suppliers. }\end{array}$ \\
\hline 15 & Stability in policy and regulations (PS) & Stability in policies and regulations, which is often tied to political stability. \\
\hline 16 & Health and safety (HS) & $\begin{array}{l}\text { Manual lifting, forceful gripping, wood dust, and hazardous substances } \\
\text { are the reported common risk factors in the wood industry. Inhaling } \\
\text { hazardous substances and getting caught in moving parts are common } \\
\text { injuries in the industry. The most prominent prior risk is inadequate } \\
\text { personal protective equipment. }\end{array}$ \\
\hline 17 & Gender diversity (GD) & $\begin{array}{l}\text { Fair representation of people of different genders at various stages of the } \\
\text { supply chain. }\end{array}$ \\
\hline 18 & Government legislation (GL) & $\begin{array}{l}\text { Regulations pressure suppliers and organizations to use eco-friendly } \\
\text { products and processes to improve operational performances. }\end{array}$ \\
\hline 19 & Top management support (TMS) & $\begin{array}{l}\text { Top management support is crucial to the successful implementation of } \\
\text { SSCM. }\end{array}$ \\
\hline 20 & Resource management (RM) & $\begin{array}{l}\text { Optimal resource usage helps firms achieve economic sustainability in the } \\
\text { supply chain. }\end{array}$ \\
\hline 21 & Supplier audit (SA) & $\begin{array}{c}\text { Supplier audits have the potential to enhance supply chains' } \\
\text { environmental and social performance. }\end{array}$ \\
\hline 22 & Product quality (PQ) & $\begin{array}{l}\text { Sustainable supply chains can be achieved by producing high-quality } \\
\text { products with a longer product life. }\end{array}$ \\
\hline 23 & $\begin{array}{l}\text { Technological advancement and } \\
\text { adaption (TAA) }\end{array}$ & $\begin{array}{l}\text { Willingness to research developing technologies and adopt new } \\
\text { technologies in the pursuit of greater sustainability. }\end{array}$ \\
\hline 24 & Technology transfer (TT) & $\begin{array}{l}\text { Transferring technology to supply chain partners helps firms achieve } \\
\text { long-term sustainability. }\end{array}$ \\
\hline 25 & Information system (IS) & $\begin{array}{c}\text { Information systems impact SSCM on various processes, such as planning, } \\
\text { sourcing, and delivering, and at various levels, including tactical } \\
\text { operations and organizational strategy. }\end{array}$ \\
\hline
\end{tabular}

\section{References}

1. Dey, B.K.; Bhuniya, S.; Sarkar, B. Involvement of Controllable Lead Time and Variable Demand for a Smart Manufacturing System under a Supply Chain Management. Expert Syst. Appl. 2021, 184, 115464. [CrossRef]

2. Bhuniya, S.; Pareek, S.; Sarkar, B. A supply chain model with service level constraints and strategies under uncertainty. Alex. Eng. J. 2021, 60, 6035-6052. [CrossRef]

3. Mahapatra, A.S. A Continuous Review Production-Inventory System with a Variable Preparation Time in a Fuzzy Random Environment. Mathematics 2021, 9, 747. [CrossRef]

4. Sardar, S.K.; Sarkar, B.; Kim, B. Integrating Machine Learning, Radio Frequency Identification, and Consignment Policy for Reducing Unreliability in Smart Supply Chain Management. Processes 2021, 9, 247. [CrossRef]

5. Krysiak, F.C. Risk management as a tool for sustainability. J. Bus. Ethics 2009, 85, 483-492. [CrossRef]

6. Dias, C.; Gouveia-Rodrigues, R.; Ferreira, J.J. Small agricultural businesses' performance-What is the role of dynamic capabilities, entrepreneurial orientation, and environmental sustainability commitment? Bus. Strategy Environ. 2021, 30, 1898-1912. [CrossRef]

7. Nguyen, T.H.; Elmagrhi, M.H.; Ntim, C.G.; Wu, Y. Environmental performance, sustainability, governance and financial performance: Evidence from heavily polluting industries in China. Bus. Strategy Environ. 2021, 30, 2313-2331. [CrossRef]

8. Pádua, S.I.D.; Jabbour, C.J.C. Promotion and evolution of sustainability performance measurement systems from a perspective of business process management: From a literature review to a pentagonal proposal. Bus. Process Manag. J. 2015, 21, 403-418. [CrossRef]

9. Moktadir, M.A.; Ali, S.M.; Jabbour, C.J.C.; Paul, A.; Ahmed, S.; Sultana, R.; Rahman, T. Key factors for energy-efficient supply chains: Implications for energy policy in emerging economies. Energy 2019, 189, 116129. [CrossRef]

10. Mark, P.; Shevchenko, A. Why Research in Sustainable Supply Chain Management Should Have No Future. J. Supply Chain. Manag. 2015, 50, 1 . 
11. Kannan, D. Role of multiple stakeholders and the critical success factor theory for the sustainable supplier selection process. Int. J. Prod. Econ. 2018, 195, 391-418. [CrossRef]

12. Luthra, S.; Garg, D.; Haleem, A. An analysis of interactions among critical success factors to implement green supply chain management towards sustainability: An Indian perspective. Resour. Policy 2015, 46, 37-50. [CrossRef]

13. Moktadir, M.A.; Dwivedi, A.; Khan, N.S.; Paul, S.K.; Khan, S.A.; Ahmed, S.; Sultana, R. Analysis of risk factors in sustainable supply chain management in an emerging economy of leather industry. J. Clean. Prod. 2021, 283, 124641. [CrossRef]

14. Al Zaabi, S.; Al Dhaheri, N.; Diabat, A. Analysis of interaction between the barriers for the implementation of sustainable supply chain management. Int. J. Adv. Manuf. Technol. 2013, 68, 895-905. [CrossRef]

15. Jahan, M.S.; Gunter, B.G.; Rahman, A.F.M.A. Substituting Wood with Nonwood Fibers in Papermaking: A Win-Win Solution for Bangladesh; SSRN: Rochester, NY, USA, 2009.

16. Razzaque, M.; Hasan, E.; Rahman, J. Furniture Exports from Bangladesh: An Analysis of Market Prospects and Policy Support; Enterprise Institute: Dhaka, Bangladesh, 2019.

17. Bovea, M.D.; Vidal, R. Materials selection for sustainable product design: A case study of wood based furniture eco-design. Mater. Des. 2004, 25, 111-116. [CrossRef]

18. González-García, S.; Berg, S.; Feijoo, G.; Moreira, M.T. Environmental impacts of forest production and supply of pulpwood: Spanish and Swedish case studies. Int. J. Life Cycle Assess. 2009, 14, 340-353. [CrossRef]

19. Romagnoli, M.; Fragiacomo, M.; Brunori, A.; Follesa, M.; Scarascia-Mugnozza, G. Solid wood and wood based composites: The challenge of sustainability looking for a short and smart supply chain. In Lecture Notes in Civil Engineering; Springer: Cham, Switzerland, 2019.

20. Khan, S.; Haleem, A.; Khan, M.I.; Abidi, M.H.; Al-Ahmari, A. Implementing Traceability Systems in Specific Supply Chain Management (SCM) through Critical Success Factors (CSFs). Sustainability 2018, 10, 204. [CrossRef]

21. Zhang, Z.; Zhang, Q.; Liu, Z.; Zheng, X. Static and Dynamic Pricing Strategies in a Closed-Loop Supply Chain with Reference Quality Effects. Sustainability 2018, 10, 157. [CrossRef]

22. Lopez, M.; Paes, Y.; Gustave, J.B.; Gonçalves, D.; Méndez, F.G.; Theodoro-Nantet, A.C. Production of wood-plastic composites using cedrela odorata sawdust waste and recycled thermoplastics mixture from post-consumer products-A sustainable approach for cleaner production in Cuba. J. Clean. Prod. 2020, 244, 118723. [CrossRef]

23. Zineldin, M.; Jonsson, P. An examination of the main factors affecting trust/commitment in supplier-dealer relationships: An empirical study of the Swedish wood industry. TQM Mag. 2000, 12, 245-266. [CrossRef]

24. Quesada, H.; Gazo, R. Methodology for determining key internal business processes based on critical success factors: A case study in furniture industry. Manag. J. 2007, 13, 5-20. [CrossRef]

25. Daian, G.; Ozarska, B. Wood waste management practices and strategies to increase sustainability standards in the Australian wooden furniture manufacturing sector. J. Clean. Prod. 2009, 17, 1594-1602. [CrossRef]

26. Dewitt, T.; Giunipero, L.C.; Melton, H.L. Clusters and supply chain management: The Amish experience. Int. J. Phys. Distrib. Logist. Manag. 2010, 36, 289-308. [CrossRef]

27. Gomez, L.S.S. Identifying Success Factors in the Wood Pallet Supply Chain; Virginia Polytechnic Institute and State University: Blacksburg, VA, USA, 2011.

28. Quesada-Pineda, H.; Araman, P.A. A Quantitative Study of the U.S. Wood Pallet Industry Based on Supply Chain Management Practices. J. Appl. Packag. Res. 2012, 6, 1-26.

29. Quesada, H.; Gazo, R.; Sanchez, S. Critical Factors Affecting Supply Chain Management: A Case Study in the US Pallet Industry. In Pathways to Supply Chain Excellence; BoD-Books on Demand: Norderstedt, Germany, 2012; pp. 33-56. [CrossRef]

30. Penfield, P.C.; Germain, R.; Smith, W. Assessing the supply chain efficiency of hardwood sawmills in new york state through case study analysis and data envelopment analysis modeling. For. Prod. J. 2014, 64, 90-96. [CrossRef]

31. Larsson, M.; Stendahl, M.; Roos, A. Supply chain management in the Swedish wood products industry-A need analysis. Scand. J. For. Res. 2016, 31, 777-787. [CrossRef]

32. Sương, T.T. Influential Factors on Supply Chain Collaboration in Vietnam'S Wood Processing Industry. J. Econ. Dev. 2018, 36-43.

33. Kogler, C.; Rauch, P. A discrete-event simulation model to test multimodal strategies for a greener and more resilient wood supply. Can. J. For. Res. 2019, 49, 1298-1310. [CrossRef]

34. Ebrahimi, M.; Tavakkoli-Moghaddam, R. A Robust Optimization Model for Joint Maintenance and Build-To-Order Supply Chain under Uncertainties: A Case Study. In Proceedings of the 15th Iran International Industrial Engineering Conference, IIIEC, Yazd, Iran, 23-24 January 2019.

35. Susanty, A.; Tjahjono, B.; Sulistyani, R.E. An investigation into circular economy practices in the traditional wooden furniture industry. Prod. Plan. Control 2020, 31, 1336-1348. [CrossRef]

36. Chu, J.; Kumar, A. Assessment of wood industrial pollutants based on emission coefficients in China. Holzforschung 2020, 74, 1071-1078. [CrossRef]

37. Ratnasingam, J.; Ioras, F.; Ark, C.K.; Latib, H.A. Success Factors of Wood Veneer as an Overlay Material for Panel-based Furniture Manufacturing in Malaysia. BioResources 2020, 15, 1311-1322.

38. Navarro, N.; Daniela, P.; Valverde, F.; Quesada, H.J.; Madrigal-sánchez, J. Industry. BioResources 2020, $15,1959-1977$.

39. Rajput, S.; Singh, S.P. Identifying Industry 4.0 IoT enablers by integrated PCA-ISM-DEMATEL approach. Manag. Decis. 2019, 57, 1784-1817. [CrossRef] 
40. Chowdhury, N.A.; Ali, S.M.; Mahtab, Z.; Rahman, T.; Kabir, G.; Paul, S.K. A structural model for investigating the driving and dependence power of supply chain risks in the readymade garment industry. J. Retail. Consum. Serv. 2019, 51, 102-113. [CrossRef]

41. Devi, K.; Paranitharan, K. Interpretive framework by analysing the enablers for implementation of Industry 4.0: An ISM approach. Total Qual. Manag. Bus. Excel. 2020, 32, 1494-1514. [CrossRef]

42. Pluskal, J.; Šomplák, R.; Nevrlý, V.; Smejkalová, V.; Pavlas, M. Strategic decisions leading to sustainable waste management: Separation, sorting and recycling possibilities. J. Clean. Prod. 2020, 278, 123359. [CrossRef]

43. Yang, G.; Zhou, C.; Wang, W.; Ma, S.; Liu, H.; Liu, Y.; Zhao, Z. Recycling sustainability of wastepaper industry in Beijing City: An analysis based on value chain and GIS model. Waste Manag. 2020, 106, 62-70. [CrossRef] [PubMed]

44. Bag, S.; Wood, L.C.; Xu, L.; Dhamija, P.; Kayikci, Y. Big data analytics as an operational excellence approach to enhance sustainable supply chain performance. Resour. Conserv. Recycl. 2019, 153, 104559. [CrossRef]

45. Rejeb, A.; Rejeb, K. Blockchain and supply chain sustainability. Logforum 2015, 16, 363-372. [CrossRef]

46. Zhang, A.; Zhong, R.Y.; Farooque, M.; Kang, K.; Venkatesh, V.G. Blockchain-based life cycle assessment: An implementation framework and system architecture. Resour. Conserv. Recycl. 2019, 152, 104512. [CrossRef]

47. Nandi, S.; Sarkis, J.; Hervani, A.A.; Helms, M.M. Redesigning Supply Chains using Blockchain-Enabled Circular Economy and COVID-19 Experiences. Sustain. Prod. Consum. 2020, 27, 10-22. [CrossRef]

48. Feitó-Cespón, M.; Costa, Y.; Pishvaee, M.S.; Cespón-Castro, R. A fuzzy inference-based scenario building in two-stage optimization framework for sustainable recycling supply chain redesign. Expert Syst. Appl. 2020, 165, 113906. [CrossRef]

49. Hu, A.H.; Hsu, C. Critical factors for implementing green supply chain management practice. Manag. Res. Rev. 2010, 33, 586-608. [CrossRef]

50. Kusi-Sarpong, S.; Gupta, H.; Sarkis, J. A supply chain sustainability innovation framework and evaluation methodology. Int. J. Prod. Res. 2018, 57, 1990-2008. [CrossRef]

51. Tay, M.Y.; Rahman, A.A.; Aziz, Y.A.; Sidek, S. A Review on Drivers and Barriers towards Sustainable Supply Chain Practices. Int. J. Soc. Sci. Humanit. 2015, 5, 892-897. [CrossRef]

52. Gouda, S.K.; Saranga, H. Sustainable supply chains for supply chain sustainability: Impact of sustainability efforts on supply chain risk. Int. J. Prod. Res. 2018, 56, 5820-5835. [CrossRef]

53. Eltayeb, T.K.; Zailani, S.; Ramayah, T. Green supply chain initiatives among certified companies in Malaysia and environmental sustainability: Investigating the outcomes. Resour. Conserv. Recycl. 2011, 55, 495-506. [CrossRef]

54. Chkanikova, O.; Sroufe, R. Third-party sustainability certifications in food retailing: Certification design from a sustainable supply chain management perspective. J. Clean. Prod. 2020, 282, 124344. [CrossRef]

55. Amiri, M.; Hashemi-Tabatabaei, M.; Ghahremanloo, M.; Keshavarz-Ghorabaee, M.; Zavadskas, E.K.; Banaitis, A. A new fuzzy BWM approach for evaluating and selecting a sustainable supplier in supply chain management. Int. J. Sustain. Dev. World Ecol. 2020, 28, 125-142. [CrossRef]

56. Atz, U.; Van Holt, T.; Douglas, E.; Whelan, T. The Return on Sustainability Investment (ROSI): Monetizing Financial Benefits of Sustainability Actions in Companies, Review of Business. Interdiscip. J. Risk Soc. 2019, 39, 1-31.

57. Power, D.J.; Sohal, A.S.; Rahman, S. Critical success factors in agile supply chain management-An empirical study. Int. J. Phys. Distrib. Logist. Manag. 2001, 31, 247-265. [CrossRef]

58. Ahmad, N.K.W.; De Brito, M.P.; Rezaei, J.; Tavasszy, L.A. An integrative framework for sustainable supply chain management practices in the oil and gas industry. J. Environ. Plan. Manag. 2016, 60, 577-601. [CrossRef]

59. Sudusinghe, J.I.; Seuring, S. Social Sustainability Empowering the Economic Sustainability in the Global Apparel Supply Chain. Sustainability 2020, 12, 2595. [CrossRef]

60. Gopalakrishnan, K.; Yusuf, Y.Y.; Musa, A.; Abubakar, T.; Ambursa, H.M. Sustainable supply chain management: A case study of British Aerospace (BAe) Systems. Int. J. Prod. Econ. 2012, 140, 193-203. [CrossRef]

61. Gardas, B.B.; Raut, R.D.; Narkhede, B. Identifying critical success factors to facilitate reusable plastic packaging towards sustainable supply chain management. J. Environ. Manag. 2019, 236, 81-92. [CrossRef] [PubMed]

62. Tran, T.M.T.; Yuen, K.F.; Li, K.X.; Balci, G.; Ma, F. A theory-driven identification and ranking of the critical success factors of sustainable shipping management. J. Clean. Prod. 2019, 243, 118401. [CrossRef]

63. Gonzalez-Padron, T.L. Ethics in the Supply Chain: Follow-Up Processes to Audit Results. J. Mark. Channels 2016, $23,22-33$. [CrossRef]

64. Saberi, S.; Kouhizadeh, M.; Sarkis, J.; Shen, L. Blockchain technology and its relationships to sustainable supply chain management. Int. J. Prod. Res. 2019, 57, 2117-2135. [CrossRef]

65. Schilling, L.; Seuring, S. Sustainable value creation through information technology-enabled supply chains in emerging markets. Int. J. Logist. Manag. 2021. (ahead of print). [CrossRef]

66. Corsi, A.; Pagani, R.N.; Kovaleski, J.L.; da Silva, V.L. Technology transfer for sustainable development: Social impacts depicted and some other answers to a few questions. J. Clean. Prod. 2019, 245, 118522. [CrossRef]

67. de Camargo Fiorini, P.; Jabbour, C.J.C. Information systems and sustainable supply chain management towards a more sustainable society: Where we are and where we are going. Int. J. Inf. Manag. 2017, 37, 241-249. [CrossRef]

68. Hasan, M.A.; Shankar, R.; Sarkis, J. A study of barriers to agile manufacturing. Int. J. Agil. Syst. Manag. 2007, 2, 1-22. [CrossRef]

69. Hasan, M.A.; Sarkis, J.; Shankar, R. Interpretive structural modelling of agility enhancing management practices for agile manufacturing. Int. J. Agil. Syst. Manag. 2013, 6, 361. [CrossRef] 
70. Bolanos, R.B.; Emilio, F.; Alfredo, N. Using interpretive structural modelling in strategic decision-making groups. J. Manag. Decis. 2005, 43, 877-895. [CrossRef]

71. Wold, S.; Esbensen, K.; Geladi, P. Principal Component Analysis. Chemometrics and Intelligent Laboratory Systems; Elsevier: Amsterdam, The Netherlands, 1987; pp. 37-52.

72. Elias, A.A.; Donadelli, F.; Paiva, E.L.; Araujo, P.P.B. Analysing the complexities of sustainable wood supply chain in the Amazon: A systems thinking approach. Int. J. Logist. Manag. 2021, 32, 1481-1505. [CrossRef]

73. Santos, A.; Carvalho, A.; Barbosa-póvoa, A.P.; Marques, A.; Amorim, P. Forest Policy and Economics Assessment and optimization of sustainable forest wood supply chains-A systematic literature review. For. Policy Econ. 2019, 105, 112-135. [CrossRef]

74. Bryant, F.B.; Yarnold, P.R. Principal-components analysis and exploratory and confirmatory factor analysis. In Reading and Understanding Multivariate Statistics; Grimm, L.G., Yarnold, P.R., Eds.; American Psychological Association: Washington, DC, USA, 1995; pp. 99-136.

75. Diabat, A.; Jebali, A. Multi-product and multi-period closed loop supply chain network design undertake-back legislation. Int. J. Prod. Econ. 2020, 231, 107879. [CrossRef]

76. Gopal, P.; Thakkar, J. Analysing critical success factors to implement sustainable supply chain practices in Indian automobile industry: A case study. Prod. Plan. Control 2016, 27, 1005-1018. [CrossRef]

77. Giannakis, M.; Dubey, R.; Vlachos, I.; Ju, Y. Supplier sustainability performance evaluation using the analytic network process. J. Clean. Prod. 2019, 247, 119439. [CrossRef] 